\title{
Characteristics of Psychiatry Consultations Requested from the Neurology Clinic, Diagnostic Congruence Rates between Psychiatrists and Neurologists
}

\section{Nöroloji Kliniğinden İstenen Psikiyatri Konsültasyonlarının Özellikleri, Psikiyatrist ve Nörologların Tanı Benzerlik Oranları}

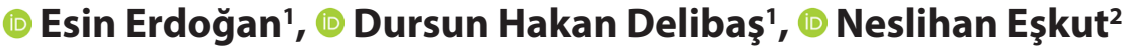 \\ 'University of Health Sciences, Izmir Bozyaka Training and Research Hospital, Department of Psychiatry, Turkey \\ ${ }^{2}$ University of Health Sciences, Izmir Bozyaka Training and Research Hospital, Department of Neurology, Turkey
}

\begin{abstract}
Introduction: Psychiatry and neurology are concerned with central nervous system dysfunctions; therefore, a common approach to said diseases is required. The aim of this study was to investigate the characteristics of psychiatric consultations, diagnostic congruence rates of psychiatric disorders, and the diagnostic accuracy between psychiatrist and neurologists in a neurology clinic of a training hospital.

Material and Method: Psychiatric consultations requested between 01.01.2017 and 01.07.2019 were evaluated retrospectively. The accuracy rate between the final psychiatric diagnosis made by the consulting psychiatrist and the initial psychiatric diagnosis made by the neurologist as well as the diagnostic congruence rate between two departments were examined.

Results: The most common reasons for consultation were agitation (36.5\%), depressive symptoms (23.9\%), and history of psychiatric treatment (18.9\%), respectively. The most common diagnoses made by psychiatrists were depressive disorders (29.7\%), anxiety disorders (18.9\%), and cognitive disorders (11.7\%). Accurate diagnosis rates were found to be high for psychotic disorders (100\%), bipolar disorder (90.9\%), alcohol/substance use disorders (A/SUD) (83.3\%) and cognitive disorders (73.7\%), and low for somatization disorders (50\%).and anxiety disorders (29.2\%). The diagnostic congruence between the two physicians was high (kappa=0.62) for A/ SUD and moderate for cognitive and depressive disorders (kappa $=0.57$, kappa=0.42).

Discussion and Conclusion: This study showed that A/SUD is well recognized by neurologists, but anxiety disorder and somatization disorder, which are commonly seen in inpatients, are poorly recognized. Due to the limited number of studies in this field, our study is valuable in emphasizing the importance of recognizing psychiatric comorbidities in the neurological patient population.
\end{abstract}

Keywords: Psychiatric consultation, psychiatric disorders, neurology, psychiatric comorbidity, inpatient
Öz

Amaç: Psikiyatri ve nöroloji merkezi sinir sistemine ait işlev bozukluklarıyla ilgilenmeleri nedeniyle ilgili hastalıklara yönelik ortak yaklaşım gerekmektedir. Bu araştırmada bir eğitim hastanesinin nöroloji kliniğinde yatarak tedavi gören hastalara istenen psikiyatri konsültasyonlarının özellikleri, psikiyatrik hastalıkların tanı benzerlik oranları ve psikiyatri hekimi ile nöroloji hekimi arasındaki psikiyatrik tanı uyumunun araştırılması amaçlanmıştır.

Gereç ve Yöntem: Ocak 2017-Temmuz 2019 tarihleri arasında istenen tüm psikiyatri konsültasyonları geriye dönük olarak değerlendirilmiş, konsültan psikiyatristin belirlediği son psikiyatrik tanı ile nöroloğun belirlediği ilk psikiyatrik tanı arasındaki doğruluk oranı ve iki branş arasındaki tanı uyumu incelenmiştir.

Bulgular: En sık konsültasyon istenme nedenleri sırasıyla ajitasyon (\%36,5), depresyon belirtileri $(\% 23,9)$ ve geçmişte psikiyatrik tedavi öyküsü $(\% 18,9)$ olarak bulunmuştur. Psikiyatristler tarafından en sık konulan tanılar depresif bozukluklar $(\% 29,7)$, anksiyete bozuklukları $(\% 18,9)$ ve kognitif bozukluklardır $(\% 11,2)$. Doğru tanınma oranları alkol/madde kullanım bozuklukları (A/MKB) $(\% 83,3)$ ve kognitif bozukluklar $(\% 73,7)$ için yüksek saptanırken, somatizasyon bozukluğu (\%50) ve anksiyete bozuklukları $(\% 29,2)$ için düşük saptanmıştır. A/MKB için iki hekim arasındaki tanı uyumu yüksek (kappa=0,62), kognitif bozukluklar ve depresif bozukluklar için orta düzeydedir (kappa=0,57, kappa=0,42).

Sonuç ve Tartışma: Bu çalışma A/MKB'nun nörologlar tarafından iyi tanındığını, ancak yatan hastalarda sıklıkla görülen anksiyete bozukluğu ve somatizasyon bozukluğunun tanısında yanılgıların yaşandığını göstermiştir. Bu alanda yapılan araştırma sayısının az olması nedeniyle araştırmamız nörolojik hasta popülasyonunda psikiyatrik eş tanıların tanınmasının önemini vurgulaması açısından değerlidir.

Anahtar Kelimeler: Psikiyatri konsültasyonu, psikiyatrik hastalıklar, nöroloji, psikiyatrik eş tanı, yatan hasta

Corresponding (IIletişim): Esin Erdoğan, University of Health Sciences, Izmir Bozyaka Training and Research Hospital, Department of Psychiatry, Turkey 


\section{INTRODUCTION}

The presence of mental disorder is often overlooked in inpatients admitted to general hospitals. ${ }^{[1-4]}$ Similar results have been reported in patients admitted to neurology clinics using standardized psychiatric clinical assessment scales. ${ }^{[5,6]}$ $39 \%$ of the patients have psychiatric symptoms, but $72 \%$ of them are not recognized by neurologists. ${ }^{[5]}$ In a study including 56 separate consultation-liaison $(\mathrm{CL})$ units, the referral rate for psychiatric opinion was $1.4 \%$ despite high comorbidity rates of $30-40 \%{ }^{[7]}$ In other words, approximately $97 \%$ of patients in a general hospital with a psychiatric diagnosis are not treated by $\mathrm{CL}$ psychiatrists. ${ }^{[1,3,8]}$

Epidemiological studies have shown that psychiatric comorbidity rates in hospitalized patients range from $41.3 \%$ to $46.5 \%{ }^{[9,10]}$ In a study conducted in Turkey, the rate of psychiatric disorders was found to be $23.4 \%$ in inpatients treated in internal and surgical wards. ${ }^{[1]]}$ The most common diagnoses in inpatients were organic mental disorder, depressive disorder, and alcohol-substance abuse. ${ }^{[0]}$ Although the rates and prevalence of comorbid psychiatric disorders vary in different studies, the presence of psychiatric comorbidity has been associated with prolonged hospital stay, increased morbidity and mortality. ${ }^{[12-14]}$ Psychiatry and neurology are concerned with central nervous system (CNS) dysfunctions and it is important that both branches collaborate for these diseases. ${ }^{[15]}$ Majority of inpatients in the neurology wards of general hospitals have psychiatric comorbidities. ${ }^{[16,17]}$ Therefore, it is important for neurologists to be able to recognize the signs and symptoms of the patient and to come up with an idea for the diagnosis and treatment while evaluating patients with a psychiatric disorder. In cerebrovascular disorder, which is the most common neurological disease, depressive disorder (DD) is reported to accompany approximately $50 \%$ of individuals. ${ }^{[18-20]}$ In addition, mood disorders are commonly seen with epilepsy and are the most important psychiatric comorbidity affecting quality of life and prognosis. ${ }^{[21]}$ In Parkinson's disease (PD), 60\% of the patients have psychiatric complaints, while depressive and anxiety disorder are the most common psychiatric disorders in PD. ${ }^{[22,23]}$ In some studies, symptoms of DD and anxiety have been reported approximately 5 years before the onset of PD. ${ }^{[24]}$ Studies report that psychiatric disorders are seen at a varying rate between 15 and $90 \%$ in patients diagnosed with multiple sclerosis (MS), and during the course of the disease a range of manifestations from depressive mood to euphoria or psychotic disorder appear. ${ }^{[25-27]}$ There are limited studies in Turkey investigating the distribution of psychiatric diagnoses in neurology wards. However, in one study investigating the psychiatric consultations requested in a general hospital, the rates of $\mathrm{DD}$, conversion disorder, and psychotic symptoms were reported to be $18.5 \%, 14.8 \%$, and $14.8 \%$, respectively. ${ }^{[28]}$ Diagnostic rate of DD among patients living in nursing homes and consultations requested with a preliminary diagnosis of DD were evaluated in a study, and it was found that DD was not sufficiently recognized by health professionals. ${ }^{[29]}$ In many studies, accurate diagnostic rates of $\mathrm{DD}^{[29-32]}$, delirium ${ }^{[3,34]}$ and conversion symptoms ${ }^{[35]}$ by non-psychiatric physicians or non-physician healthcare workers were investigated. Dilts et al. investigated the accuracy of psychiatric diagnoses in the $\mathrm{CL}$ service for the first time in the literature. ${ }^{[36]}$ They found that cognitive and SUD were correctly recognized by non-psychiatric physicians to a large extent, but only half of the depressive patients were diagnosed. ${ }^{\left[{ }^{[3]}\right.}$ Although there are many studies on psychiatric comorbidity and outcomes in inpatients, the number of studies investigating accurate diagnostic rates by non-psychiatric physicians is limited. ${ }^{[4,37,38]}$ In two studies in Turkey, the accurate diagnostic rates of psychiatric diseases by non-psychiatric physicians were investigated in the $\mathrm{CL}$ services of university hospitals. ${ }^{[13,39]} \mathrm{To}$ the best of our knowledge, there is no study investigating the accurate diagnostic rate of psychiatric diseases by neurologists in neurology patients admitted to a general hospital.

In this study, all psychiatry consultations requested for onsite evaluation of patients hospitalized in the neurology ward within a period of 2.5 years were evaluated retrospectively, and the aim of the study was to investigate the characteristics of the consultations, accurate diagnosis rate of the neurologist responsible for the patient's primary care, and the congruence with the psychiatric diagnosis made by the consultant psychiatrist.

\section{MATERIAL AND METHOD}

In this study, all on-site psychiatric consultations requested by the Neurology Clinic of Izmir Bozyaka Training and Research Hospital between 01.01.2017 and 07.01.2019 were evaluated retrospectively by reviewing the data on the hospital information management system (HIMS). To screen the files retrospectively, written consent was obtained from the head physician of the hospital's comittee within the scope of good clinical practice (07.08.2019/124-4). Demographic information, reason for requesting consultation, neurological diagnosis and clinical characteristics, psychiatric diagnosis according to DSM-IV diagnostic criteria were filled out by reviewing patient records. The primary neurological diagnosis of patients for whom psychiatric consultation was requested was made by neurologists using the World Health Organization's Classification System (ICD 10), which was registered in the HIMS database.

As in a previous similar study, after consultation and evaluation of the cases by the psychiatrist, all patients who were diagnosed as unipolar depressive disorder, bipolar depressive disorder, dysthymic disorder, depressive disorder due to general medical condition or drug use were included in the DD group. ${ }^{[13]}$ Delirium, all dementia types, organic mental disorders and amnestic disorders were classified as cognitive disorders. The general psychiatric diagnoses made by the neurologists were matched with DSM-IV diagnoses. For example, the consultation request of the neurologists to evaluate a patient with depressive mood led us to conclude 
that the neurology physician was suspicious of DD, and the preliminary diagnoses such as depressive mood, pessimism, and depression were considered as depressive disorders.

SPSS 22 statistical package program was used for data analysis. Descriptive statistics such as mean, standard deviation and percentage distributions, as well as parametric tests such as Student's $t$ test and Chi-square test for categorical variables were used to evaluate the data. Diagnostic accuracy in psychiatric consultations was calculated by the ratio of the diagnoses confirmed by psychiatrists to all consultations requested by neurologists for that diagnosis. For each psychiatric diagnosis category, whether there was a statistically significant difference between the psychiatric diagnoses of the two branches was examined by chi-square test and Kappa statistic was used to evaluate the diagnostic congruence between the two branches. $P<0.05$ was considered statistically significant.

\section{RESULTS}

There were 222 patients over the age of 18 who were requested to be consulted for mental health and diseases within a 2.5-year period. In the same period, the total number of patients admitted to the neurology unit was 3675. Psychiatric consultation was requested for $6.4 \%$ of all patients hospitalized in the neurology unit. The mean age of the patients was 55.44 \pm 1.71 (female:54.82 \pm 1.85 , male:53.27 \pm 1.61$)$. Other sociodemographic characteristics of the patients are given in Table 1.

\begin{tabular}{|c|c|c|}
\hline Age (mean \pm sd) & \multicolumn{2}{|c|}{$55.44 \pm 1.71$} \\
\hline Sex & & \\
\hline Female & $n=110$ & $(49.5 \%)$ \\
\hline Male & $\mathrm{n}=112$ & $(50.5 \%)$ \\
\hline \multicolumn{3}{|l|}{ Marital Status } \\
\hline Single & $\mathrm{n}=48$ & $(21.6 \%)$ \\
\hline Married & $n=125$ & $(56.3 \%)$ \\
\hline Widowed/divorced & $\mathrm{n}=49$ & $(22.1 \%)$ \\
\hline \multicolumn{3}{|l|}{ Employment Status } \\
\hline Unemployed & $\mathrm{n}=182$ & $(82 \%)$ \\
\hline Employed & $n=40$ & $(18 \%)$ \\
\hline \multicolumn{3}{|l|}{ Socioeconomic Status } \\
\hline Low & $\mathrm{n}=72$ & (32.4\%) \\
\hline Middle & $n=145$ & (65.3\%) \\
\hline High & $\mathrm{n}=5$ & $(2.3 \%)$ \\
\hline
\end{tabular}

$32.9 \%(n=73)$ of the patients for whom consultation was requested had previously received psychiatric treatment. Four patients were found to have attempted suicide during hospitalization to the neurology unit. The mean duration of hospitalization in the neurology unit was 8.95 \pm 7.21 (1-45) days, the mean number of hospitalizations was $1.77 \pm 1.75$ (1-14) times, the mean time until psychiatric consultation requested was $3.91 \pm 4.62(0-38)$ days, and the number of psychiatric consultations requested during hospitalization was $1.12 \pm 0.37$ (1-3).

"Agitation" was the most common reason for psychiatric consultation by neurology physicians ( $\mathrm{n}=81,36.5 \%)$. Depressive symptoms $(n=53,23.9 \%)$ and past psychiatric disorder/treatment history $(n=42,18.9 \%)$ were among the leading reasons for consultation. The other stated reasons for consultation are given in Table $\mathbf{2}$.

\begin{tabular}{lcc}
\multicolumn{3}{l}{ Table 2. Distribution of reasons for psychiatric consultation for patients } \\
\hline Agitation & $\mathbf{n}$ & $\%$ \\
Depressive symptoms & 81 & 36.5 \\
History of past psychiatric treatment & 53 & 23.9 \\
Application to Health Board & 42 & 18.9 \\
Not specified & 27 & 12.2 \\
Considering delirium & 7 & 3.2 \\
Conversion & 4 & 1.8 \\
Insomnia & 3 & 1.4 \\
Smoking cessation & 2 & 0.9 \\
Suicide attempt & 1 & 0.5 \\
Presence of self-destructive thinking & 1 & 0.5 \\
\hline
\end{tabular}

Ischemic cerebrovascular event $(n=72,32.4 \%), M S(n=37$, $16.7 \%)$, epilepsy $(n=27,12.2 \%)$ and PD $(n=25,11.3 \%)$ were the most common diagnoses for hospitalization in the neurology clinic. When the distribution of psychiatric diagnoses of the patients after evaluation of the psychiatric consultation team were examined, most common diagnoses were depressive disorders (29.7\%), anxiety disorders (18.9\%), and cognitive disorders $(11.2 \%)$. The distribution of the diagnosis of psychiatric disorders is shown in Table 3.

Table 3. Diagnostic distribution of psychiatric disorders in inpatients after consultation $(n=222)$

\begin{tabular}{lcc} 
& $\mathbf{n}$ & $\%$ \\
\hline Depressive Disorders & 66 & 29.7 \\
Anxiety Disorders & 42 & 18.9 \\
No Active Psychopathology & 26 & 11.7 \\
Cognitive Disorders & 25 & 11.2 \\
Alcohol-Substance Use Disorders & 13 & 5.9 \\
Conversion-Somatoform Disorders & 13 & 5.9 \\
Bipolar Disorder & 12 & 5.4 \\
Psychotic Disorders & 12 & 5.4 \\
Others & 8 & 3.6 \\
Adjustment Disorder & 5 & 2.3 \\
\hline Cognitive Disorders: Delirium, organic mental disorder, dementia & & \\
Others: Mental retardation, sleep disorder, simulation & & \\
\hline
\end{tabular}

According to the results of this study, accurate diagnosis rate of depressive disorders was found to be $63.0 \%$. Alcohol/ substance use disorders (A/SUD) were accurately diagnosed by neurology physicians at a rate of $83.3 \%$. Congruence rate between the neurologist and the consultant psychiatrist was 
$50 \%$ for conversion and somatoform disorders and $29.2 \%$ for anxiety disorders. In 83 (36\%) patients, psychiatric prediagnosis was not indicated in the consultation request. Diagnostic congruence rates between the neurologist and consultant psychiatrist for other diagnoses are shown in Table 4.

For five categories of psychiatric disorders, the diagnostic agreement between the two branches was investigated with the kappa statistics. Psychotic disorders and bipolar disorders are not analysed due to the low number of cases. It was found that there was a statistically significant difference in depressive disorders between the initial diagnosis (DD diagnosed by neurologist) and the final diagnosis (DD diagnosed by psychiatrist $(p<0.001)$ and the diagnostic agreement between the two physicians was moderate (kappa value $=0.424$ ). There was a statistically significant difference between the initial and final diagnoses in anxiety disorders and somatoform disorders ( $p=0.027, p=0.024)$, and the congruence between the two physicians was poor (kappa $=0.25$; $k a p p a=0.28$ ) for both groups. Congruence rates between the two physicians for other diagnoses are given in Table $\mathbf{5}$.

Table 4. Preliminary diagnoses indicated by the neurologist, and similarity and difference rates of these diagnoses after the evaluation of patients

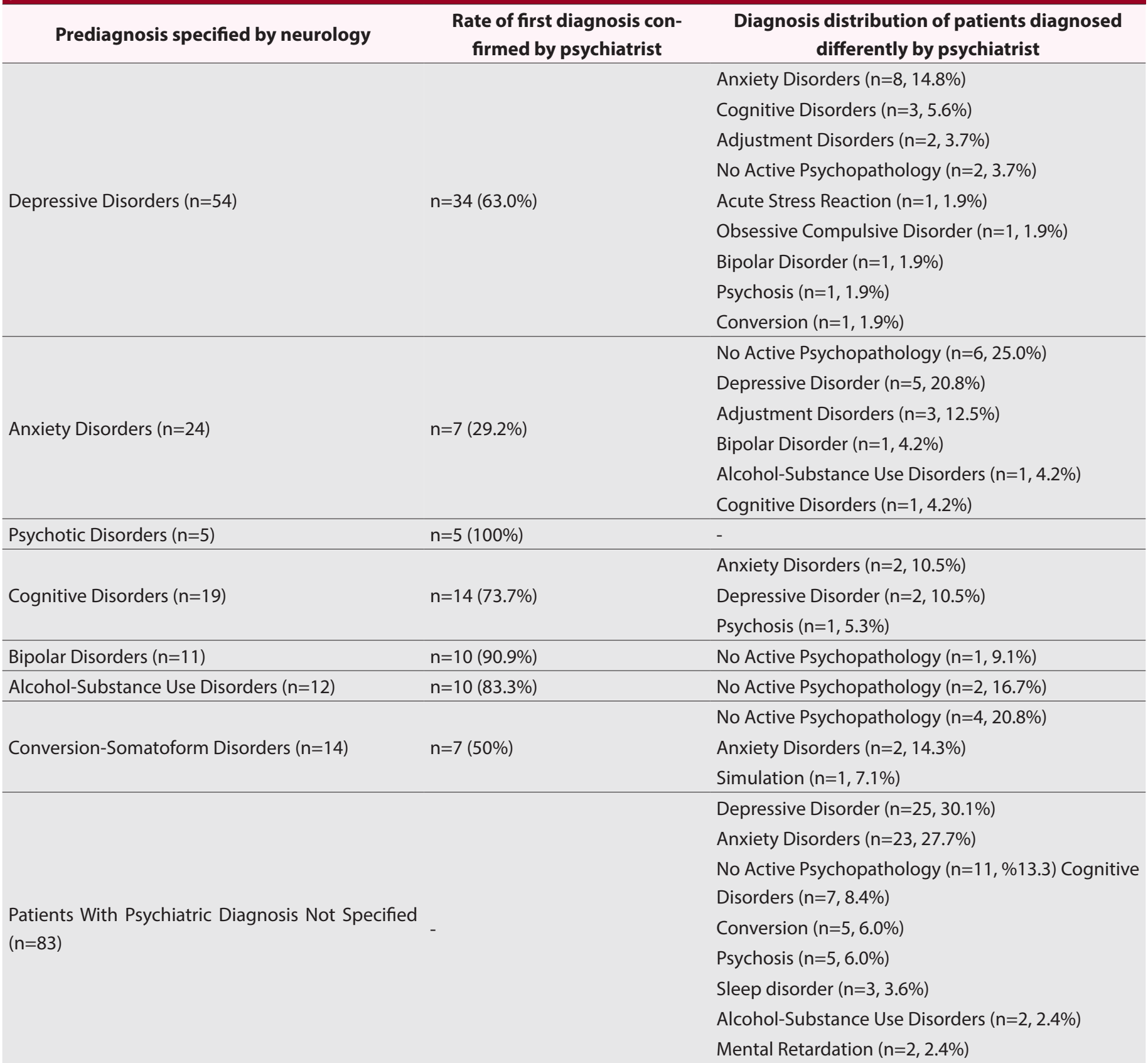


Table 5. Diagnostic accuracy between the two branches in terms of psychiatric disorders

\begin{tabular}{|c|c|c|c|}
\hline Psychiatric Disorders & Positive Expected Value & Ki-square test & Kappa Value \\
\hline Depressive Disorders & $63 \%(34 / 54)$ & $<0.001$ & 0.424 \\
\hline Anxiety Disorders & $29.2 \%(7 / 24)$ & 0.027 & 0.25 \\
\hline Cognitive Disorders & $73.7 \%(14 / 19)$ & 0.280 & 0.57 \\
\hline Alcohol-Substance Use Disorders & $83.3 \%(10 / 12)$ & 0.523 & 0.62 \\
\hline Conversion-Somatoform Disorders & $50.1 \%(6 / 12)$ & 0.024 & 0.28 \\
\hline \multicolumn{4}{|l|}{$\begin{array}{l}p<0.05 \text { statistically significant } \\
\text { Value of Kappa Level of Agreement }\end{array}$} \\
\hline $0.01-0.20 \quad$ None & & & \\
\hline $0.21-0.40$ & & & \\
\hline $0.41-0.60$ & & & \\
\hline Moderate-Strong & & & \\
\hline
\end{tabular}

\section{DISCUSSION}

The frequency and clinical characteristics of psychiatric consultations requested for inpatients in the neurology clinic of a training hospital and the congruence rates of psychiatric diagnoses between the two branches were investigated over a 2.5-year period. In previous studies conducted in Turkey consultation rate from the psychiatric department varies between 1.37 and $2.80 \% .{ }^{[40-42]}$ In the present study, psychiatric consultation was requested for $6.4 \%$ of neurology patients. This is slightly higher than the rates reported in the literature..$^{[7,17,43]}$ Studies in Turkey have shown that consultation rate is higher in internal medicine branches. ${ }^{[43,44]}$ The fact that neurology and psychiatry are concerned with closely related disorders may explain the need for higher rates of consultation observed in this study. ${ }^{[15,17]}$

In the present study, $32.9 \%$ of the patients for whom psychiatric consultation was requested stated that they had received psychiatric treatment before. This result is consistent with other studies in the literature. ${ }^{[40,45]}$ Neurology patients needing the support of another person to provide daily functionality is among the factors that create a predisposition in individuals for the development of mental disorders. ${ }^{[7,46]}$ The majority of the cases (80.6\%) needed support for self-care. The mean duration of hospitalization was 8.95 days, and psychiatric consultation was requested in the early period of hospitalization on average 1.12 times and within 3.91 days. Because of the high rate of psychiatric comorbidity in neurology patients, if treatment planning is not performed, the course of primary disease and treatment outcomes are affected. ${ }^{[7,15]}$ It is known that early diagnosis of psychiatric comorbidities, and initiation of treatment contribute to the treatment process of the primary disease. As a result of psychiatric consultation, psychiatric treatment was initiated in the majority of the patients (75.1\%).

Agitation (36.5\%), depressive symptoms (23.9\%) and history of psychiatric treatment (18.9\%) were the main reasons for consultation. In previous studies, the reasons for consultation were $12.8-54.4 \%$ for agitation, $13.0-24.5 \%$ for depressive signs and symptoms, and $10.1 \%$ for previous psychiatric diagnosis and treatment. ${ }^{[28,42,45,47-50]}$ The results obtained in the present study are consistent with the literature, except for history of psychiatric treatment. The varying rates obtained in different studies can be due to reasons such as study populations (general hospital sample, internal/surgical clinics, etc.), physicians not being able to recognize psychiatric disorders correctly or not using the appropriate terminology when requesting consultation, and neurologists having more information about psychiatric diseases compared to other branches. ${ }^{[48]}$

The results of our study showed that psychotic disorders, bipolar disorders, A/SUD and cognitive disorders were well recognized by neurologists, but anxiety disorders and conversion-somatoform disorders, which are frequently seen in inpatients, were poorly recognized. This finding was not consistent with the results of Dilts et al. ${ }^{[36]}$ It is seen that although the prevalence of SUD is high in inpatients, there are difficulties in diagnosis. ${ }^{[51-53]}$ The rate of accurate diagnosis for SUD ranges from $7 \%$ to $89 \%$ in different studies. ${ }^{[52]}$ Similar to our study, Sertöz et al. also reported that A/SUD was well recognized by non-psychiatric physicians and anxiety disorder was poorly recognized. ${ }^{[13]}$ In another study, the diagnostic accuracy of psychiatric disorders in internal and surgical units of a university hospital was evaluated as $60 \%$ for cognitive disorders, $50 \%$ for depressive disorder, $46 \%$ for anxiety disorders, and $0 \%$ for the diagnosis of psychosis. ${ }^{[54]}$ In the present study, active psychopathology was not detected after psychiatric evaluation in two of the patients who were requested for consultation with the diagnosis of $A$ /SUD. The reason why A/SUD are well recognized by neurologists may be due to diligently receiving clinical history from the patients, may be related to their experience in neuropsychiatric pathologies resulting from alcohol/substance use, or due to the fact that these patients are often hospitalized because of physical illnesses that develop due to alcohol consumption.

In the patients requested consultations for evaluation of cognitive disorders; two had DD, two patients had anxiety disorder and one patient had psychotic disorder. Symptoms such as negativistic attitudes, somatic complaints, difficulty in maintaining attention and concentration, and forgetfulness, which are among the clinical signs of DD and anxiety, should be considered especially in patients who are evaluated with a preliminary diagnosis of delirium or dementia by neurologists. [29,55] Similarly, apathy and psychomotor deceleration, which 
are common symptoms in both DD and hypoactive delirium, may have led neurologists to decide in favor of delirium or dementia. Also, disorganized speech and failure to maintain purpose-oriented activities seen in psychotic disorders should be considered in congitive evaluation.

DD were correctly recognized by neurologists at a rate of $63 \%$, and moderate agreement was found between the two branches. In terms of DDs, anxiety disorder (14.8\%), cognitive disorder (5.6\%), and adjustment disorder (3.7\%) were the most common changing diagnoses after psychiatric evaluation. The results showed that neurology physicians particularly had difficulty in recognizing the symptoms of anxiety disorder. In the literature, it has been reported that DDs are often confused with cognitive disorders. ${ }^{[36,56]}$ Ekmekçi et al. reported in their study that delirium, anxiety disorders and alcoholsubstance use disorders were the diseases with the highest rates of confirmation by psychiatry. ${ }^{[39]}$

In our study, accurate diagnosis rates of anxiety disorders and somatoform disorders were lower than other disease groups. DD was found in $20.8 \%$ and adjustment disorder was found in $12.5 \%$ of the patients who were consulted by neurologists with a preliminary diagnosis of anxiety disorder. Active psychopathology was not detected in $25 \%$ of these cases. Anxiety that occurs in patients with a medical illness is generally interpreted by non-psychiatric physicians as a normal response associated with physical illness or uncertainty about treatment. ${ }^{[57]}$ Since anxiety can also be a symptom of a mood disorder or other psychiatric disorder, it is important to recognize it and evaluate for treatment. ${ }^{[30]}$

Medically unexplained physical symptoms sometimes lead physicians to consider cases as somatization disorder. There are studies in the literature reporting that conversion and somatization symptoms are recognized by non-psychiatric physicians at a rate of $96-100 \% \cdot{ }^{[36,58]}$ Psychiatric diagnoses of patients referred by neurologists differ from other branches especially in terms of the diagnosis frequency of somatoform and dissociative disorders. When the relationship between neurological and psychiatric disorders is examined, most of these cases may also exhibit somatization disorder, since an organic basis for symptoms cannot be found in approximately $30 \%$ of neurological patients. ${ }^{[59,60]}$ Ewald et al. reported that 14 of 100 neurological inpatients had a diagnosis of somatization disorder without organic medical disease, and 26 had both an organic disease and non-organic symptoms. ${ }^{[59]}$ In addition, somatic complaints may also be a symptom of DD or anxiety. [61] Consistent with this data, active psychopathology was not detected in $20.8 \%$ of the patients with a pre-diagnosis of somatoform disorder, and $14.3 \%$ were diagnosed with anxiety disorder. $50 \%$ of 12 patients with a pre-diagnosis of somatoform disorder were also diagnosed as somatoform disorder by psychiatrists.

In this study, $37 \%$ of the consultations requested could not be classified in any diagnostic category by neurologists. The majority of these cases were diagnosed with DD and anxiety disorder by a psychiatrist. In an other study examining all hospital consultations, this rate was reported to be $72 \%{ }^{\left[{ }^{[39]}\right.}$ In our opinion, this may have led to a decrease in the accurate diagnosis rate of psychiatric disorders. These results are consistent with the literature indicating that DD and anxiety disorders are not sufficiently recognized by non-psychiatric physicians. ${ }^{[56,62,63]}$ For this reason, this study has led us to realize that the frequency of the disorders in the spectrum of $\mathrm{DD}$ and anxiety seen in neurological diseases is quite high, and that we gain awareness that neurologists and psychiatrists will work together in order to plan joint trainings in order to recognize their clinical symptoms more easily.

Some of the significant limitations encountered during the study are the retrospective design of the study, its inclusion of a single center, the lack of face-to-face interviews with the physician requesting consultation on a case by case basis, neurologists not classifying the diagnoses based on DSM and the exclusion of personality disorders.

\section{CONCLUSION}

This study showed that A/SUD and cognitive disorders were well recognized by neurologists, but the recognition rate of anxiety and somatization disorders was low. Psychiatric education within the scope of medical and specialty education mainly focuses on psychiatric morbidity in the population included in the field of mental health. This affects health professionals' recognition of psychiatric disorders in general hospitals and subsequent psychiatric referral. Considering the effect of the presence of psychiatric comorbidity on mortality, morbidity and length of hospital stay, we believe that the results of our study are valuable in terms of emphasizing the importance of recognizing psychiatric comorbidities in the neurological patient population.

\section{ETHICAL DECLARATIONS}

Ethics Committee Approval: The study was carried out with the permission of Neurology Clinic of Izmir Bozyaka Training and Research Hospital Ethics Committee within the scope of good clinical practice (Permission granted: 07.08.2019, Decision no: 124-4).

To screen the files retrospectively, written consent was obtained from the head physician of the hospital's comittee within the scope of good clinical practice (07.08.2019/124-4).

Informed Consent: Because the study was designed retrospectively, no written informed consent form was obtained from patients.

Referee Evaluation Process: Externally peer-reviewed.

Conflict of Interest Statement: The authors have no conflicts of interest to declare.

Financial Disclosure: The authors declared that this study has received no financial support.

Author Contributions: All of the authors declare that they have all participated in the design, execution, and analysis of the paper, and that they have approved the final version.

\section{REFERENCES}

1. Mayou R, Hawton K. Psychiatric disorder in the general hospital. Br J Psychiatry 1986;149:172-90. 
2. Drayer RA, Mulsant BH, Lenze EJ et al. Somatic symptoms of depression in elderly patients with medical comorbidities. Int J Geriatric Psychiatry 2005;20:973-82.

3. Kessler R, Demler O, Frank R et al. Prevalence and treatment of mental disorders, 1990 to 2003. N Eng J Med 2005;352(24):2515-23.

4. Waheed S, Rabbani G, Al Mamun A et al. Psychiatric patients at general hospital emergency departments. Bang J Psychiatry 2017;31(1):7-14.

5. Bridges KW, Goldberg DP. Psychiatric illness in inpatients with neurological disorders: patients? Views on discussion of emotional problems with neurologists. Br Med J 1984;289:656-65.

6. Metcalfe R, Firth D, Pollock S, Creed F. Psychiatric morbidity and illness behaviour in female neurological inpatients. J Neurol Neurosurg Psychiatry 1988;51:1387-90.

7. Huyse FJ, Herzog T, Lobo A et al. European consultation-liaison psychiatric services: the ECLW collaborative study. Acta Psychiatr Scand 2000;101:360-6.

8. Chisholm D, Flisher AJ, Lund C et al. Scale up services for mental disorders: A call for action. Lancet 2007;370(9594): 1241-52.

9. Rothenhausler HB. Mental disorders in general hospital patients. Psychiatr Danub 2006;18:183-92.

10. Hochlehnert A, Niehoff D, Herzog W, Löwe B. Elevated costs of treatment in medical inpatients with psychiatric comorbidity are not reflected in the German DRG-system. Psychother Psychoso Med Psychol 2007;57(2):70-5.

11. Ateşci FÇ, Karadağ, F, Oğuzhanoğlu, NK. Bir üniversite hastanesinde yatan hastalarda psikiyatrik bozukluk dağılımı. Anadolu Psikiyatri Derg 2000;1(3):148-56.

12. Furlanetto LM, da Silva RV. The impact of psychiatric comorbidity on length of stay of medical inpatients. Gen Hosp Psychiatry 2003;25(1):1419.

13. Sertöz ÖÖ, Doğanavşargil GÖ, Noyan MA, Altıntoprak E, Elbi H. Bir üniversite hastanesi konsültasyon liyezon servisinde psikiyatrik hastalıkların psikiyatri dışı hekimlerce doğru tanınma oranları. Klinik Psikofarmakoloji Bülteni. 2008;18(4).

14. Goulia P, Mantas C, Hyphantis T. Delirium, a 'confusing' condition in general hospitals: The experience of a consultation-Liaison Psychiatry Unit in Greece. Int J Gen Med 2009;2:201-7.

15. Atbaşoğlu C, Sakarya D. Psikiyatride sık görülen nöropsikiyatrik sendromlara yaklaşım. Psikiyatride Güncel 2011;2:156-71.

16. Fricchione G, Weilburg JB, Murray GB. Neurology and neurosurgery. In: Rundell JR, Wise M, editors. Text book for C-L Psychiatry. Washington, DC: American Psychiatric Press; 1996. p. 258-76.

17. de Jonge $P$, Huyse FJ, Herzog $T$ et al. Referral pattern of neurological patients to psychiatric Consultation-Liaison Services in 33 European hospitals. Gen Hosp Psychiatry 2001;23:152-7.

18. Tiller JWG. Post stroke depression. Psychopharmacology 1992;106:130-3.

19. Yılmaz H, Kesiktaş N, Karamehmetoğlu şS, Bozkurt T. İnme (serebrovasküler hastalık) sonrası oluşan depresyonun diğer klinik özelliklerle karşılaştırılması. Düşünen Adam 1995;8(2):27-30.

20. Bayam G, Dilbaz N, Özalp E, Güz H. İnme sonrası duygudurum bozuklukları. Klinik Psikiyatri 2001;4:154-65.

21. Kesebir S, Güven S, Koç I. Epilepsi ve duygudurum bozuklukları. Psikiyatride Güncel Yaklaşımlar 2012;4(1):51-68.

22. Aarsland D, Larsen JP, Lim NG et al. Range of neuropsychiatric disturbances in patients with Parkinson's disease. J Neurol Neurosurg Psychiatry 1999;67:492-6.

23. Tunç T, Emre U, Coşkun Ö, Okuyucu E, Yandı Vargel S, İnan LE. Parkinson hastalığında anksiyete bozukluğu. Parkinson Hast Hareket Boz Dergisi 2007;10(1-2):22-5.

24. Shiba M, Bower JH, Mraganore DM et al. Anxiety disorders and depressive disorders preceding Parkinson's disease: a case control study. Mov Disord 2000;15:669-77.
25. Pine DS, Douglas CJ, Charles E et al. Patients with multiple sclerosis presenting to psychiatric hospitals. J Clin Psychiatry 1997;58:297-308.

26. Mindel SL. Mood disorders in multiple sclerosis: diagnosis and treatment. J Neurovirol 2000;6:160-7.

27. Emre U, Ergün U, Yıldız H, Coşkun Ö, İnan LE. Multipl skleroz ve psikiyatrik hastalıklar. Düşünen Adam 2003;16(1):46-9.

28. Eser B, Batmaz S, Songur E, Yıldız M, Akpınar Aslan E. Bir üniversite hastanesinde yatan hastalar için ve acil servisten istenilen ruh sağlığı ve hastalıkları konsültasyonlarının incelenmesi: Türkiye'den çalışmalarla bir karşılaştırma. Klinik Psikiyatri 2018;21:278-89.

29. Leo RJ, Sherry C, DiMartino S, Karuza J. Psychiatric consultation in the nursing home: Referral patterns and recognition of depression. J Psychosom Res 2002;53:783-7.

30. Rincon HG, Granodos M, Unutzer J et al. Prevalence, dedection and treatment of anxiety, depression, and delirium in the adult critical care unit Psychosomatics 2001;42:391-6.

31. Boland RJ, Diaz S, Lamdan RM, Ramchandani D, McCartney JR Overdiagnosis of depression in the general hospital. Gen Hosp Psychiatry 1996;18:28-35.

32. Igwe MN, Uwakwe R, Ahanotu CA, Onyeama GM, Bakare MO, Ndukuba AC. Factors associated with depression and suicide among patients with diabetes mellitus and essential hypertension in a Nigerian teaching hospital. Afr Health Sci 2013;13(1):68-77.

33. Elie M, Rousseau F, Cole M, Primeau F, McCusker J, Bellavance F. Prevalence and detection of delirium in elderly emergency department patients. Can Med Assoc J 2000;163:977-81.

34. Hustey FM, Meldon SW, Palmer R. The prevalence and documentation of impaired mental status in elderly emergency department patients. Ann Emerg Med 2002;39:248-53.

35. Stone J, Smyth R, Carson A et al. Systematic review of misdiagnosis of conversion symptoms and hysteria. BMJ 2005;331:1-6.

36. Dilts SL, Mann N, Dilts JG. Accuracy of referring psychiatric diagnosis on a consultation-liaison service. Psychosomatics 2003;44: 407-11.

37. Ngui EM, Khasakhala L, Ndetei D, Weiss R. Mental disorders, health inequalities and ethics: A global perspective. Int Rev Psychiatry 2010;22(3):235-44.

38. Bahçeci B, Güveli H, Kandemir G, Aslan M, Köroğlu A. The evaluation of psychiatric pre-diagnoses diagnosed by non-psychiatric doctors in an adult emergency service. J Kartal Training Research Hosp 2011;22(2):659.

39. Ekmekci Ertek İ, Öztürk HM. Bir eğitim-araştırma hastanesinde istenen psikiyatri konsültasyonlarının değerlendirilmesi ve psikiyatrik hastalıkların doğru tanınma oranları. Klinik Psikiyatri 2019;22:338-46.

40. Canan F, Koçer E, İçmeli C, Özçetin A, Ataoğlu A. Bir üniversite hastanesinde yatan hastalar için istenen psikiyatri konsültasyonlarının değerlendirilmesi. Düzce Tıp Fak Derg 2008;1:22-7.

41. Köroğlu A, Çelik FH, Aslan $M$, Hocaoğlu Ç. Bir eğitim hastanesinde psikiyatri konsültasyon hizmetlerinin değerlendirilmesi. Klinik Psikiyatri 2011;14:44-50

42. Kahyacı Kılıç E, Köse Çınar R, Sönmez MB, Görgülü Y. Bir üniversite hastanesinde yatan hastalardan istenen psikiyatrik konsültasyonların değerlendirilmesi. Klinik Psikiyatri 2016;19:194-201.

43. Diefenbacher A, Strain JJ. Consultation-liaison psychiatry: stability and change over a 10-year-period. Gen Hosp Psychiatry 2002;24:249-56.

44. Yıldız M, Tural Ü, Kesepara C, Aydın M, Etuş H. Fiziksel hastalıklara eşlik eden ruhsal bozukluklar: Bir üniversite hastanesinde psikiyatri konsültasyon sonuçlarının değerlendirilmesi. Düşünen Adam: Psikiyatri Nörolojik Bilimler Derg 2002;15:21-4.

45. Bass C, Bolton J, Wilkinson P. Referrals to a liaison psychiatry out-patient clinic in a UK general hospital: a report on 900 cases. Acta Psychiatr Scand 2002; 105(2):117-25. 
46. Özmen E, Aydemir Ö. Bir genel hastanede istenen psikiyatri konsültasyonları. Nöropsikiyatr Arş 1993;30:459-65.

47. Aslan Ş, Ateşci F. Bir üniversite hastanesinde yatan hastalardan istenen psikiyatri konsültasyonlarının geriye dönük incelenmesi. Türk Psikiyatr Derg 2017;28(2):74-5.

48. Göktaş K, Yılmaz E, Kaya N, Akman C. Bir eğitim hastanesinde istenen psikiyatri konsültasyonlarının değerlendirilmesi. Anadolu Psikiyatri Derg 2006;7:27-32.

49. Güneysu I, Akpınar Aslan E, Batmaz S. Bir üniversite hastanesinde istenilen psikiyatri konsültasyonlarındaki deliryum olgularının değerlendirilmesi. Türk Psikiyatri Derg 2017;28(2):88.

50. Sarandöl A, Akkaya C, Eker S ve ark. Uludağ Üniversitesi Tıp Fakültesi Psikiyatri Anabilim Dalı Konsültasyon Liyezon Psikiyatrisi polikliniğinin ilk bir yılında istenen konsültasyonların değerlendirilmesi: 2071 olgu. Türkiye'de Psikiyatri 2007,9:26-31.

51. Alaja R, Seppa K, Sillanaukee P et al. Physical and mental comorbidity of substance use disorders in psychiatric consultations. European Consultation-Liaison Workgroup. Alcohol Clin Exp Res 1998;22:1820-24.

52. Chen $\mathrm{CH}$, Chen WJ, Cheng ATA. Prevalence and identification of alcohol use disorders among nonpsychiatric inpatients in one general hospital. Gen Hosp Psychiatry 2004;26:219-25.

53. Okulate GT, Odunaike A. Alcohol use and abuse among medical and surgical in patients in a general hospital. Niger Postgrad Med J 2005;12:7780.

54. Al-Hutail YR. Accuracy of referring psychiatric diagnosis. Int J Health Sci 2008;2(1):35-8.

55. Stiefel FC, de Jonge P, Huyse FJ, et al. A method to assess health service needs: results on its validity and clinical use. Gen Hosp Psychiatry1999;21:49-56.

56. Leo RJ, Sherry C, Jones AW. Referral patterns and recognition of depression among African-American and Caucasian patients. Gen Hosp Psychiatry 1998;20:175-82.

57. Epstein SA, Hicks D. Anxiety disorders. In Levenson JM (editor). Textbook of Psychosomatic Medicine. Washington, DC: American Psychiatric Publishing Inc, 2005. p. 251.

58. Stone J, Smyth R, Carson A, Lewis S, Prescott R, Warlow C, Sharpe M. Systematic review of misdiagnosis of conversion symptoms and hysteria. BMJ 2005;331(989):1-6.

59. Ewald H, Rogne T, Ewald K, Fink P. Somatisation in patients newly admitted to a neurological department. Acta Psychiatr Scand 1994;89:174-179.

60. McKee K, Glass S, Adams C, Stephen CD, King F, Parlman K, Perez D, Kontos $\mathrm{N}$. The inpatient assessment and management of motor functional neurological disorders: An interdisciplinary perspective. Psychosomatics 2018;59(4):358-68.

61. Blancha CG, de-Hitaa FH, Navarroc RM, Rodríguezd PR, Medranoe LA, Morianaf JA, Vindel AC. Domain-specific associations between disability and depression, anxiety, and somatization in primary care patients. Psychiatry Research 2018;269:596-601.

62. Newport DJ, Nemeroff CB. Assessment and treatment of depression in the cancer patient: J Psychosom Res 1998; 45:215-37.

63. Young AS, Klap R, Sherbourne CD, Wells KB. The quality of care for depressive and anxiety disorders in the United States: Arch Gen Psychiatry 2001;58: 55-61. 